\title{
Butterflies of Sanjay Gandhi National Park, Mumbai, Maharashtra, India
}

Study Area: India, Mumbai

\section{Amol P Patwardhan*}

Department of Zoology, K. J. Somaiya College of Science and Commerce, Vidyavihar, Mumbai 400077, Maharashtra, India.

Coordinates: $19^{\circ} 15^{\prime} \mathrm{N} 72^{\circ} 55^{\prime} \mathrm{E}$

Key words: National Park, Butterflies, Hotspot.

\section{Abstract}

Sanjay Gandhi National Park (SGNP) is spread over 103 sq km in Mumbai and Thane districts of Maharashtra, India. During the study I have sighted 142 species of butterflies with another 7 unconfirmed sightings. The butterflies recorded belong to Papilionidae (10 spp.), Pieridae (17 spp), Lycaenidae (47 spp.), Nymphalidae (40 spp.) and Hesperiidae (28 spp.). The study emphasizes the importance of this park as a hotspot which is surrounded by 17 million people.

\section{Introduction}

Sanjay Gandhi National Park (SGNP) is spread over $103 \mathrm{sq} \mathrm{km} \mathrm{in} \mathrm{Mumbai} \mathrm{suburban} \mathrm{and} \mathrm{Thane}$ districts. The vegetation of the Park is primarily tropical dry deciduous with a few patches of evergreen forest. The Park has more than 1000 species of flora (pers. comm. Students of Dr. Almeida). The area is hilly with numerous water channels flowing eastwards, southwards, westwards and northwards.

Butterflies of Mumbai have been documented by Aitkin \& Comber (1903a \& b), Bell (1909 to 1927) and Best (1951). de Niceville (1890) and Wynter Blyth (1957) reported many species from 'Bombay' now Mumbai. Gaonkar (1996) reported 330 species from the entire Western Ghats and 208 species from the Northern Western Ghats in Maharashtra. From the adjoining state, Goa, Borkar \& Komarpant (2004) studied habitats for 91 species and Rangnekar (2007) described 90 species. Kurve \& Patwardhan (2005) reported 129 species from SGNP and 51 species from adjoining Thane city. Chaturvedi \& Kehimkar (pers. comm.) recorded approximately 140 species from SGNP.

*Corresponding Author: amolppatwardhan@gmail.com 


\section{Materials and Methods}

The study was done once a week from three different areas viz. Silonda, Yeoor and Nagla during June 2002 to June 2013. The observation time was from $07.00 \mathrm{hrs}$ in the morning to 12.00 noon. The butterflies were observed along paths inside the forest and along water streams. They were observed on both sides of the paths. Lycaenids and hesperids were caught in the net whenever required, identified and released. In case of uncertain identity photographs were taken. The classification follows Evans (1932), Kehimkar (2008), Kunte (2000) and Wynter Blyth (1957). Their status was decided on visual observations as C - common, VC - very common, NC not common, $\mathrm{R}$ rare, $\mathrm{VR}$ very rare. This status does not correlate to the entire geographical distribution status of a corresponding species. The months during which the particular species was on the wings are given as Flight months.

\section{Results and Discussion:}

Overall, 142 species (149 species including unconf irmed sightings) were recorded Overall, 142 species (149 species including unconfirmed sightings) were recorded from SGNP. Five families (Fig. 1) were recorded with the decreasing order of dominance as follows: Lycaenidae (47 species; 33.62\%) > Nymphalidae (40 species; 28.37\%) > Hesperidae (28 species; 19.86\%) > Pieridae (17 species; $12.06 \%$ ) > Papilionidae (10 species; $7.09 \%)$.

In all 18 subfamilies were recorded out of which Nymphalidae dominated with 7 and Lycaenidae with 5 subfamilies (Table 1, Fig. 2). Papilionidae was represented by only one subfamily.

Figure- 3 is represnting the family wise distribution of diversity per status. The status Very Common, Common and Not Common had representation from all the families. Family Papilionidae did not show any Rare or Very Rare species. Family Pieridae had only one species with status VR, Chocolate Albatross $A$. lyncida. In Lycaenidae, 4 species were VR viz. Redspot

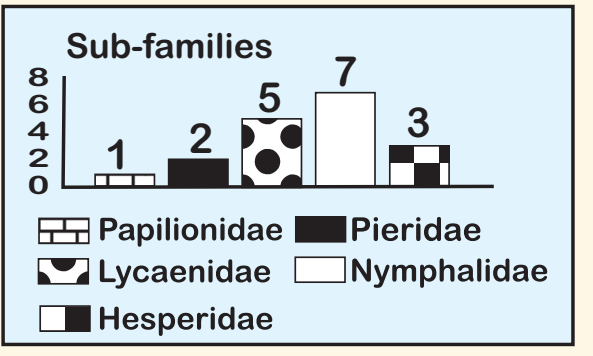

Fig. 2. Family wise diversity of sub families Zesius chrysomallus, Tufted White Royal Pratapa deva, Common Tinsel Catapaecilma elegans and Abnormal Silverline Spindasis abnormis. In Hesperiidae $35.17 \%$ diversity was distributed in status Common and Not Common. The Lycaenidae comprised of $36.9 \%$ Common and $35.18 \%$ Not Common species. In Nymphalidae $46.15 \%$ species were of common status where as in Pieridae and Papilionidae had Common status species dominant with $52.9 \%$ and $60 \%$ diversity respectively. 


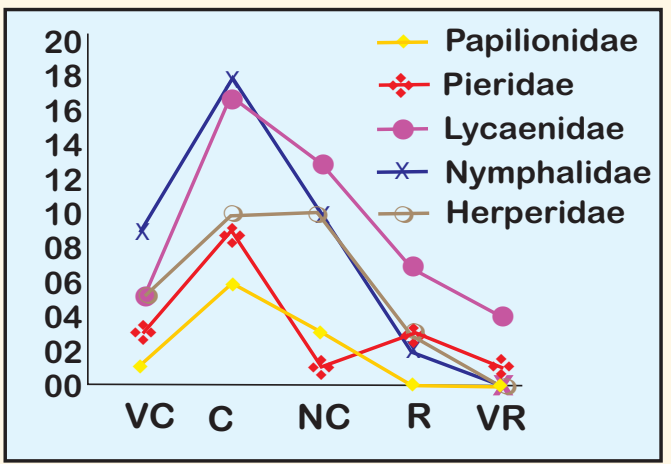

Fig. 3. Family wise diversity of species per status

It was observed that there were 60 species with 'Common' status. This is the highest diversity amongst all the status. 37 species categorized under 'Not Common' while 23 species under 'Very Common'. There were 15 'Rare' and only 5 'Very Rare' species. (Fig. 4)

Figure- 5 is representing the month wise distribution of the diversity. The highest diversity of species observed was in Feb Apr followed by May Jun and Oct Jan. around 110 species were recorded in the months of Jul Sept. During the monsoon i.e. June to September the density and diversity of butterflies was expected to be high, however it did not appear to be so. The probable reason was, during monsoon the leaf cover of the

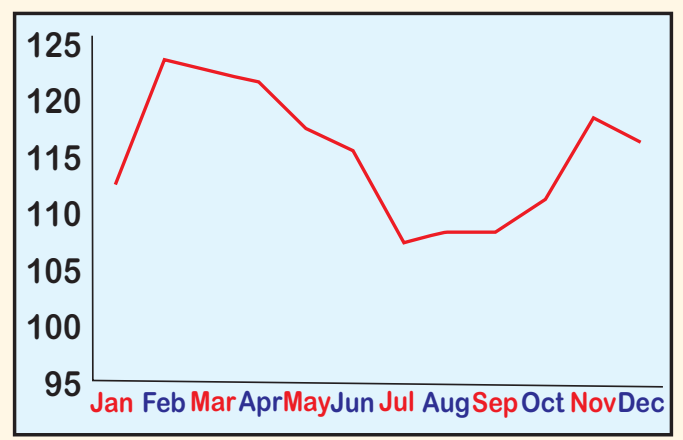

Fig. 5. Month wise distribution of the butterfly diversity area increases

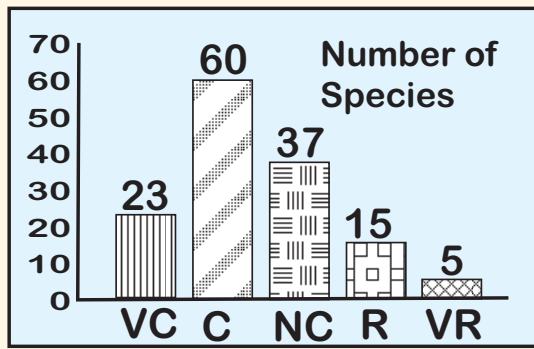

Fig. 4. Status wise diversity of species tremendously hence visibility reduces. Secondly the ambient moisture content is high with humidity almost touching $100 \%$ hence the butterflies are not required to come out on to the streams or wet soil in search of water. October November period is the season for wild flower blooming hence the butterflies can be sighted frequently in spite of the thick vegetation and high moisture. On the other hand during January May period the leaf cover goes on reducing as the forest is of dry deciduous type. February April is period when highest diversity was observed when butterflies visit drying water bodies for minerals. On 4th March 2007, 70 species were recorded between 8.0o AM to 14.0o PM.

\section{Family Papillionidae:}

Three species out of ten recorded were not seen commonly. Those were Crimson Rose A. hector, Common Mime P. clytia and Blue Mormon P. polymnestor. The dissimilis form of Common Mime was more common than the clytia form. Blue Mormon P. polymnestor is found in greater numbers during the monsoon season. Except Atrophaneura spp. all the other species were seen mud puddling. Spot Swordtail $P$. nomius was recorded in very large numbers during the dry season (January May) when many individuals were seen

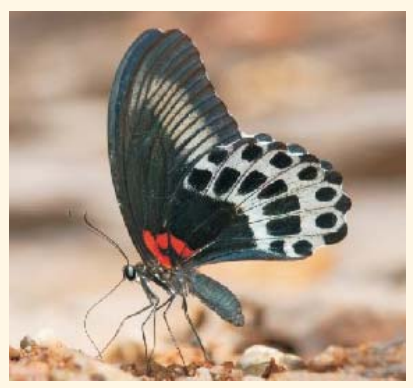

Blue Mormon 
mud puddling together on wet patches of soil.

\section{Family Pieridae:}

Amongst orange tips, the White Orange Tip I. marianne was not as common as the other two Orange Tips. In Yellow Orange Tip I. pyrene, the yellow female form is commoner than the white form. One white form of female was photographed on 26th August 2005. The female of Common Gull C. nerissa was

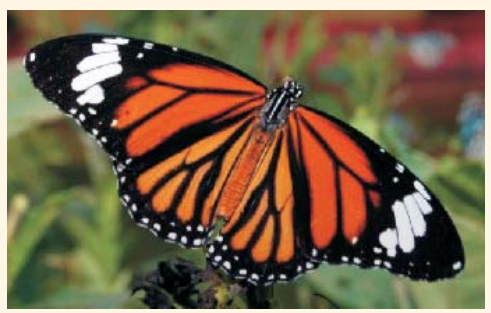

Striped Tiger rarer than the male. Pioneer A. aurota, although rare throughout Silonda and Nagla, was never seen in Yeoor. The Small Salmon Arab C. amata was very common in Nagla block where its food plant Meswak Salvadora persica is abundant along the Ulhas River Estuary. There were two sightings of Small Salmon Arab in Yeoor area on 1oth October 2004 and 2nd November 2008 reported by Patwardhan (2010). Its occurrence in Yeoor which is at least $2 \mathrm{~km}$ away from the estuary, is probably related to wind drift as otherwise Meswak is not found in the area and no other known food plant has yet been reported. The philomela form of female Common wanderer P. valeria was rare and was seen only during post monsoon season (Oct -Dec). Patwardhan (2010) recorded one specimen of Chocolate Albatross A. lyncida was seen on 29th October 2006 and a second on 2nd November 2009. Though this appears to be a range extension, this species does not seem to have established itself here. It might be migrating northwards but further observations in nearby areas are required. Common Albatross A. albina was seen in the months of February and March 2010 in Nagla block at drying pools engaged in mud puddling with others.

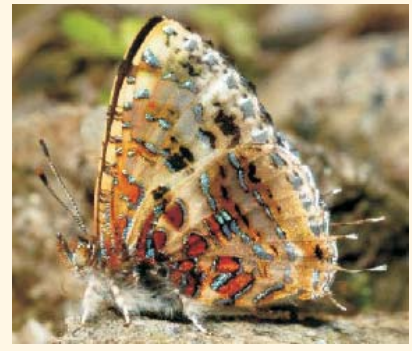

Common Tinsel
Family Lycaenidae:

Redspot Z. chrysomallus female was seen mud puddling in Nagla block on 22nd February 2009 by Patwardhan (2010). Second specimen, a female, was seen on 21st February 2010 on the same patch. Bell (1919) reported it from 'Malda', now Malad, which is close to the western boundary of SGNP. Wynter-Blyth (1957) reported it from 'Bombay' which is probably the same location. de Nicéville (1890) reported it from Alibag, District Raigad. Hence the present sightings become more important as it was sighted after a gap of almost 50 years in the same area. Recently there are records of the caterpillars from the outskirts of the sanctuary (pers. comm. Sarang Mhatre).

On 25th February 2007, I photographed one male Tufted White Royal P. deva in Nagla (2010). He had just eclosed from the chrysalis. He had pupated on the bark of Kusum Schliechera oliosa just two feet above the ground. de Nicéville (189o); Evans (1932); Gaonkar (1996) and Wynter Blyth (1957) reported it as Rare. This species is decidedly rare and encountered very less than the Peacock Royal T. cippus.

Common Tinsel C. elegans a single specimen was photographed on 14th March 2010 in Nagla block by Yuvraj Gurjar (pers. comm.). One specimen of Abnormal Silverline S. abnormis 
was photographed mud puddling in Yeoor range. This appears to be the northern most record of this species within its endemic range in Western Ghats. Western Centaur Oakblue $A$. pseudocentaurus was the commonest of the Arhopala species at Nagla block whereas in Yeoor and Borvili the Large Oakblue A. amantes was the commonest.

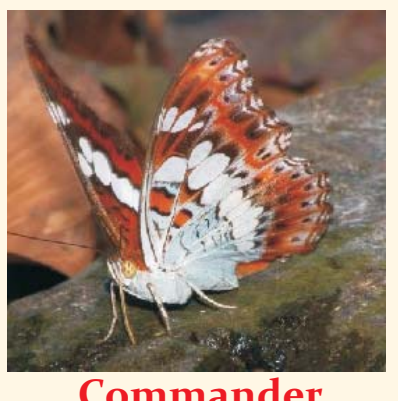

Commander

Plains Cupid C. pandava was seen settling on wet patches of soil for mud puddling. I have seen more than twenty individuals sitting together on mud. Another species that likes to sit in larger group is the Zebra Blue L. plinius.

\section{Family Nymphalidae:}

Amongst nymphalids, the commonest species were Common Evening Brown M. leda, Common Bushbrown M. perseus, Common Sailer N. hylas, Common Crow E. core and Tigers except Dark blue Tiger T. septentrionis. Chestnut Streaked Sailer N. jumbah and Short banded Sailer N. columella were common only during the dry season when they frequent wet patches with Common Sailer N. hylas. Blue Pansy J. orithya and Yellow pansy J. hierta were not so common during monsoon (June-September) and post monsoon (October-December). All the Pansies were recorded mud puddling. Baronet $S$. nais was only seen along the forest paths and never in thickets. It has the habit of flying in front of the person and after a while flies back to its earlier perch. Gaudy baron E. lubentina was only seen during the driest season during which it was a frequent visitor to wet soil patches. Among Charaxinae, Black Rajah C. solon and Anomalous Nawab P. agraria were Rare throughout the study period.

When decaying prawns or crabs were put as bait, the earliest species to visit were Common bushbrown M. perseus, Blue oak leaf $K$. horsfieldii. Tawny Rajah C. bernardus and Common Nawab P. athamas arrived as the ambient temperature increase by the day.

\section{Family Hesperiidae:}

Brown Awl B. exclamationis was the commonest of the Awls followed by Plain Banded Awl $H$. vitta and Common banded awl H. chromus. Orange awlet B. jaina appears to be seasonal and was seen only during monsoon (June-September). Brown Awl visited wet soil patches during the driest season (March-May). Among Subfamily Pyrginae, Spotted Small Flat S. purendra was Rare, whereas other Flats and Angles were not so rare. Golden angle $C$. ransonnetti and Malabar spotted flat $C$. ambaressa were very common. The Tamil Grass Dart Taractrocera cermas, Dark Palm Dart Telicota ancilla and Pale palm dart T. colon were more common during monsoon. This abundance might be related to heavy growth of grasses. Further study is required to ascertain this. Grass demon $U$. folus was common throughout the study period. Wynter-Blyth reports 'Thana' now Thane, as a place to observe Vindhyan bob A. vindhiana. Apparently this species is more common in Yeoor than the other areas of SGNP. Sometimes it is as common as Rice swift B. cinnara at some places. The occurrence of Indian Palm bob $S$. gremius is sporadic inside the park. There are also records of Orange tail awl B. sena fro Borivli 
and Nagla region (pers. comm.Mr. Nelson Rodrigues)

Suspected presence/Unconfirmed sightings::

Plain Puffin (Appias indra Moore, 1857): On 24/9/2009, I saw one specimen flying rapidly over the bushes. It was probably a male. He settled on the flower of Leea microphyla for a moment before disappearing into a thicket.

Metallic cerulean Jamides alecto: I suspect that I saw this species on the flowers of Trema spp. in Yeoor in July 2007 but before approaching for the closer inspection it flew away. Transparent 6 line blue Nacaduba kurava, Opaque 6 line blue N. beroe and Dingy line blue Petrelaea dana. These line blues appear to visit wet soil for puddling. There are some unconf irmed personal sightings of these species.

Dark Evening Brown Melanitis phedima: It is suspected to be present but definite identification is pending.

Acknowledgements

I am thankful to the Forest Dept., Maharashtra State for permitting my entry into the park. I am also thankful to numerous friends who assisted during field visits. Kishen Das for providing a copy of Wynter-Blyth and to Alka Bhagwat for providing several references.

\section{References}

Aitkin E.H. \& Comber E. (1903a): A list of Butterflies of Konkan. J. Bomb. Nat. His. Soc., 15:42-55.

Aitkin E.H. \& Comber E. (1903b): Further notes on Konkan butterflies. L. Bomb. Nat. His. Soc. 15:356-357.

Bell T.R. (1909 to 1927): The common butterflies of plains of India (including those met within the hill stations of Bombay Presidency).J. Bomb. Nat. His. Soc., 19 (1) - 31 (4).

Best A.E.G. (1951):The Butterflies of Bombay and Salsette. J. Bomb. Nat. His. Soc., 50:331-339.

Borkar M.R. \& Komarpant N. (2004): Diversity, abundance, and habitat associations of butterfly species in Bondla wildlife sanctuary of Goa, India. Zoo's Print, 19(10):1648-1653.

de Niceville L.(1890): The Butterflies of India, Burmah and Ceylon. Vol. III. Re-published by A. J. Reprints Agency., New Delhi 503p.

Evans W.H. (1932): The Identification of Indian Butterflies. Second Ed. Revised. Published by Bombay Natural History Society, Bombay (1985 reprint). 454p.

Gaonkar H. (1996): Butterflies of the Western Ghats, India (including Sri Lanka): A biodiversity assessment of a threatened mountain system. Report to the Centre of Ecological Sciences, I.I. Sc., Bangalore. 86 p.

Kehimkar I. (2008): The Book of Indian Butterflies. Published by Bombay Natural History Society, Mumbai. 497 p.

Kunte K. (2000): Butterflies of Peninsular India (India:A Lifescape). Universities Press (India) Ltd, Hyderabad 272 p.

Kurve P. \& Patwardhan A. (2005): Comparative study of butterflies from urbanized zone, degraded forest and core forest in and around Thane city, Mumbai: Minor project submitted to the University of Mumbai. 72 p.

Patwardhan A. (2010): Sightings of rare butterfly species and new record from Sanjay Gandhi National Park, Mumbai and Tungareshwar Sanctuary, Thane, India. Zoo's Print, 25 (5):19-20.

Rangnekar P. (2007): A Photographic Guide to Butterflies of Goa. (also includes butterflies of other ranges of the Western Ghats \& Southern India). Mineral Foundation of Goa, 66pp.

Wynter-Blyth M.A. (1957).:Butterflies of the Indian Region. Reprint 1982, Today and Tomorrow's Printers and Publishers, New Delhi. 523p. 
Table 1: Species composition of butterflies recorded from SGNP

\begin{tabular}{|llllllllll|}
\hline S.No & $\begin{array}{l}\text { Family } \\
\text { Species }\end{array}$ & No. of & $\begin{array}{l}\% \\
\text { families }\end{array}$ & Sub & VC & C & NC & R & VR \\
\hline 1. & Papilionidae & 10 & 7.09 & 1 & 1 & 6 & 3 & - & - \\
\hline 2. & Pieridae & 17 & 12.06 & 2 & 3 & 9 & 1 & 3 & 1 \\
\hline 3. & Lycaenidae & 47 & 32.62 & 5 & 5 & 17 & 13 & 8 & 4 \\
\hline 4. & Nymphalidae & 40 & 28.37 & 7 & 9 & 18 & 10 & 2 & - \\
\hline 5. & Hesperidae & 28 & 19.86 & 3 & 5 & 10 & 10 & 3 & - \\
\hline & Total & 142 & 100 & 18 & 23 & 60 & 37 & 16 & 5 \\
\hline
\end{tabular}

Table 2: Species composition of butterflies (Species; Sight; Flight Months)

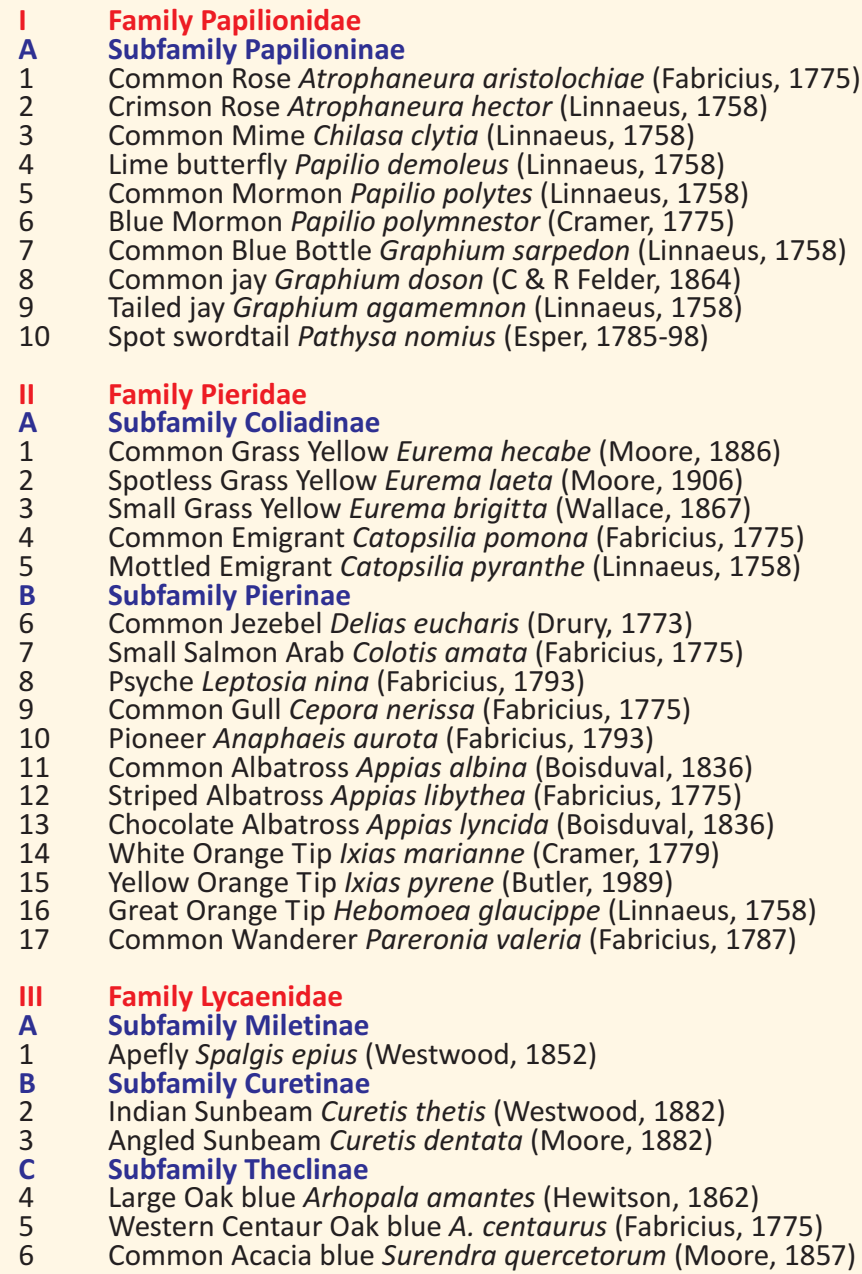

Crimson Rose Atrophaneura hector (Linnaeus, 1758)

Common Mime Chilasa clytia (Linnaeus, 1758)

Common Blue Bottle Graphium sarpedon (Linnaeus, 1758)

Common jay Graphium doson (C \& R Felder, 1864)

Tailed jay Graphium agamemnon (Linnaeus, 1758)

Family Pieridae

Spotless Grass Yellow Eurema laeta (Moore, 1906)

Small Grass Yellow Eurema brigitta (Wallace, 1867)

Common Emigrant Catopsilia pomona (Fabricius,

Subfamily Pierinae

Common Jezebel Delias eucharis (Drury, 1773)

Psyche Leptosia nina (Fabricius, 1793)

Common Gull Cepora nerissa (Fabricius, 1775

Poner Anaphaeis aurota (Fabricius, 1793)

Striped Albatross Appias libythea (Fabric

White Orange Tip Ixias marianne (Cramer, 1779)

Yellow Orange Tip Ixias pyrene (Butler, 1989)

Great Orange Tip Hebomoea glaucippe (Linnaeus, 1758)

Family Lycaenidae

Apefly Spalgis epius (Westwood, 1852)

Subfamily Theclinae

Western Centaur Oak blue $A$ centaurus (Fabricius, 1775)

Common Acacia blue Surendra quercetorum (Moore, 1857)

Status

Flight months

$\begin{array}{ll}\text { C } & 6-12 \\ \text { NC } & 6-12 \\ \text { NC } & 1-12 \\ \text { C } & 1-12 \\ \text { C } & 1-12 \\ \text { NC } & 6-11 \\ \text { C } & 1-12 \\ \text { C } & 1-12 \\ \text { C } & 1-12 \\ \text { VC } & 1-6,11,12\end{array}$

$\begin{array}{ll}\text { VC } & 1-12 \\ \text { C } & 1-12 \\ \text { C } & 1-12 \\ \text { C } & 1-12 \\ \text { C } & 1-12 \\ \text { C } & 1-12 \\ \text { C } & 1-12 \\ \text { VC } & 1-12 \\ \text { VC } & 1-12 \\ \text { R } & 1-4 \\ \text { R } & 2,3 \\ \text { R } & 1-4 \\ \text { VR } & 11 \\ \text { NC } & 1-12 \\ \text { C } & 1-12 \\ \text { C } & 1-12 \\ \text { C } & 1-12\end{array}$

$\begin{array}{ll}\text { R } & 1,2,5-12 \\ \text { C } & 1-12 \\ \text { C } & 1-12 \\ \text { NC } & 1-4,11,12 \\ \text { NC } & 1-4,11,12 \\ \text { C } & 6-12\end{array}$


Leaf blue Amblypodia anita (Hewitson, 1862)

Silverstreak blue Iraota timoleon (Stoll, 1790)

Yamfly Loxura atymnus (Cramer, 1782)

Monkey Puzzle Rathinda amor (Fabricius, 1775)

Redspot Zesius chrysomallus (Hubner, 1819)

Peacock Royal Tajuria cippus (Fabricius, 1798)

Tufted White Royal Pratapa deva (Moore, 1884)

Guava blue Deudorix isocrates (Fabricius, 1793)

Cornelian Deudorix epijarbas (Moore, 1858 )

Indian Red Flash Rapala iarbas (Fabricius, 1787)

Indian Slate Flash Rapala manea (Moore, 1879)

Indigo Flash Rapala varuna (Hewitson, 1863)

Common Tinsel Catapaecilma elegans (Druce, 1873)

Common Silverline Spindasis vulcanus (Moore, 1881)

Long banded Silverline Spindasis lohita (Moore, )

Shot Silverline Spindasis ictis (Hewitson, 1865)

Abnormal Silverline Spindasis abnormis (Moore, 1883)

Subfamily Polyomamtinae

Pointed Cilliate blue Anthene lycaenina (R. Felder, 1868)

Common Pierrot Castalius rosimon (Fabricius,1775)

Angled Pierrot Caleta caleta(Hewitson,1876)

Rounded Pierrot Tarucus nara (Kollar, 1848)

Zebra blue Leptotes plinius (Fabricius,1793)

Dark Grass blue Zizeeria karsandra(Moore, 1865)

Pale Grass blue Pseudozizeeria maha (Kollar, 1844)

Tiny Grass blue Zizula hylax (Fabricius,1775)

Lesser Grass blue Zizina otis (Fabricius,1787)

Grass Jewel Freyria trochilus (Freyer, 1845)

Gram blue Euchrysops cnejus (Fabricius, 1798)

Pea blue Lampides boeticus (Linneaus, 1767)

Common Cerulean Jamides celeno (Cramer, 1775)

Dark Cerulean Jamides bochus (Stoll, 1782)

Forget me not Catochrysops strabo (Fabricius, 1793)

Common Line blue Prosotas nora (C. Felder, 1860)

Tailless Line blue Prosotas dubiosa (Semper, 1879)

Dingy Lineblue Petrelaea dana (de Nicéville, 1883)

Malayan Megisba malaya (Moore, 1879)

Common Hedge blue Acytolepis puspa (Horsfield, 1828)

Indian Cupid Everes lacturnus (Godart, 1824)

Plains Cupid Chilades pandava (Horsfield, 1892)

Lime blue Chilades laius (Cramer, 1878)

Subfamily Riodininae

Plum Judy Abisara echerius (Moore, 1878)

Family Nymphalidae

Subfamily Danainae

Plain Tiger Danaus chryssipus (Linneaus, 1758)

Striped Tiger Danaus genutia (Cramer, 1779)

Blue Tiger Tirumala limniace (Butler, 1886)

Dark blue Tiger Tirumala septentrionis (Butler, 1874)

Glassy Tiger Parantica aglea (Moore, 1883)

Common Crow Euploea core (Cramer, 1790)

Brown king Crow Euploea klugii (Moore, 1858)

Subfamily Charaxinae

Tawny Rajah Charaxes bernardus (C. \& R.Felder, 1867)

Black Rajah Charaxes solon (Fabricius, 1781)

Common Nawab Polyura athamas (Drury, 1770)

Anomalous Nawab Polyura agraria (Swinhoe, 1887)

Subfamily Satyrinae

Common Evening brown Melanitis leda (Cramer, 1775)

Bamboo Tree brown Lethe europa (Fruhstorfer, 1911)

Common Bush brown Mycalesis perseus (Fabricius, 1798)

Dark brand Bush brown Mycalesis mineus (Linnaeus, 1765)

$\begin{array}{ll}\text { NC } & 1-6 \\ \text { R } & 3-5,11 \\ \text { NC } & 6-12 \\ \text { NC } & 1-12 \\ \text { VR } & 3 \\ \text { R } & 2,-5,10,11 \\ \text { VR } & 2 \\ \text { R } & 2-5 \\ \text { R } & 2-9 \\ \text { C } & 2-5 \\ \text { C } & 1-5,8-12 \\ C & 2-4 \\ \text { VR } & 3 \\ \text { NC } & 1-12 \\ \text { NC } & 1-12 \\ \text { R } & 1-6 \\ \text { VR } & 2\end{array}$

R $1-5$

C 1-12

NC $1-12$

NC $\quad 1-12$

C $1-6,11,12$

VC $1-12$

NC $\quad 1-12$

C 1-12

C 1-12

NC 1-12

VC $1-12$

C 1-12

VC $1-12$

C 1-12

NC 1-6,10-12

C 1-12

VC 1-12

$\mathrm{R} \quad 1-5$

C 1-6,12

C $1-12$

NC 1-5,10-12

C 1-12

C 1-12

VC

1-12

$\begin{array}{ll}\text { VC } & 1-12 \\ \text { VC } & 1-12 \\ \text { VC } & 1-12 \\ \text { C } & 2-5 \\ \text { VC } & 1-12 \\ \text { VC } & 1-12 \\ \text { C } & 1-12 \\ \text { NC } & 1-5,11,12 \\ \text { R } & 1-12 \\ \text { NC } & 1-12 \\ \text { R } & 1-12 \\ & \\ \text { C } & 1-12 \\ \text { NC } & 1-12 \\ \text { C } & 1-12 \\ \text { NC } & 1-12\end{array}$


Long Brand Bush brown Mycalesis visala (Moore, 1858)

Common Four Ring Ypthima huebneri (Kirby, 1871)

Common Five Ring Ypthima baldus (Fabricius, 1775)

Common Palmfly Elymnias hypermenstra (Linneaus, 1763)

Subfamily Heliconinae

Tawny Coaster Acraea violae (Horsfield, 1829)

Common Leopard Phalanta phalantha (Drury, 1770)

Subfamily Limenitinae

Commander Moduza procris (Cramer, 1777)

Chestnut Streaked Sailer Neptis jumbah (Moore, 1857)

Common Sailer Neptis hylas (Moore, 1872)

Short banded Sailer Neptis columella (Cramer, 1780)

Common Baron Euthalia aconthea (Hewitson, 1874)

Gaudy Baron Euthalia lubentina (Cramer, 1777)

Baronet Symphadra nais (Forster, 1771)

Subfamily Biblidinae

Common Castor Ariadne merione (Cramer, 1771)

Angled Castor Ariadne ariadne (Linnaeus, 1763)

Subfamily Nymphalinae

Painted Lady Cynthia cardui (Linnaeus, 1758)

Yellow Pansy Junonia hierta (Evans, 1923)

Blue Pansy Junonia orithya (Huebner, 1816)

Lemon Pansy Junonia lemonias (Linnaeus, 1758)

Peacock Pansy Junonia almana (Linnaeus, 1758)

Grey Pansy Junonia atlites (Johanssen, 1764)

Chocolate Pansy Precis iphita (Cramer, 1779)

Danaid Eggfly Hypolimnas missipus (Linnaeus, 1764)

Great Eggfly Hypolimnas bolina (Linnaeus, 1758)

Blue Oak leaf Kallima horsfieldi (Kollar, 1844)

Family Hesperiidae

Subfamily Coeliadinae

Brown Awl Badamia exclamationis (Fabricius, 1775)

Plain Banded Awl Hasora vitta (Butler, 1870)

Common Banded Awl Hasora chromus (Cramer, 1780)

Common Awl Hasora badra (Moore, 1858)

Orange Awlet Bibasis jaina (Moore,1866)

Subfamily Pyrginae

Malabar Spotted Flat Celaenorrhinus ambareesa (Moore,1866)

Common Spotted Flat Celaenorrhinus leucocera (Kollar, 1844)

Tricolored Pied Flat Coladenia indrani (Moore,1866)

Fulvous Pied Flat Pseudocoladenia dan (Fabricius, 1787)

Common Small Flat Sarangesa dasahara (Moore,1866)

Spotted Small Flat Sarangessa purendra (Moore, 1882)

Golden Angle Caprona ransonnetti (R. Felder, 1868)

Angled Flat Tapena thwaitesi (Moore, 1881)

Indian Skipper Spialia galba (Fabricius, 1793)

Subfamily Hesperiinae

Tamil Grass Dart Taractrocera ceramas (Hewitson, 1868)

Dark Palm Dart Telicota ancilla (Herrich-Schaeffer, 1869)

Pale Palm Dart Telicota colon (Fabricius, 1775)

Grass Demon Udaspes folus (Cramer, 1775)

Common Red Eye Matapa aria (Moore, 1866)

Straight Swift Parnara guttatus (Bremer \& Grey, 1852)

Rice Swift Borbo cinnara (Wallace, 1866)

Small Branded Swift Pelopidas mathias (Fabricius, 1798)

Great Swift Pelopidas assamensis (de Niceville, 1882)

Conjoined Swift Pelopidas conjuncta (Herrich-Schäffer, 1869)

Chestnut Bob lambrix salsala (Moore, 1866)

Vindhyan Bob Arnetta vindhiana (Moore, 1884)

Indian Palm Bob Suastus gremius (Fabricius, 1798)

Moore's Ace Halpe porus (Mabille, 1877)

$\begin{array}{ll}\text { C } & 1-12 \\ \text { NC } & 1-12 \\ \text { C } & 1-12 \\ \text { NC } & 1-12 \\ \text { C } & 1-12 \\ \text { VC } & 1-12 \\ C & 1-12 \\ C & 2-6 \\ C & 1-12 \\ \text { NC } & 2-6 \\ C & 1-12 \\ \text { NC } & 1-6,11,12 \\ \text { VC } & 1-12 \\ & \\ C & 1-12 \\ C & 1-12 \\ & \\ \text { NC } & 1-12 \\ \text { NC } & 2-6 \\ \text { NC } & 2-6 \\ C & 1-12 \\ C & 1-12 \\ C & 1-12 \\ C & 1-12 \\ \text { VC } & 1-12 \\ \text { VC } & 1-12 \\ \text { C } & 1-12\end{array}$

C $\quad 1-12$

C $\quad 6-11$

C 6-11

NC $\quad 1-4,10-12$

R $6-10$

VC $1-12$

C $\quad 1-12$

C $1-12$

NC $\quad 1-12$

NC $1-12$

$\mathrm{R} \quad 1-12$

VC $1-12$

NC $1-6$

NC $\quad 6-12$

C 7-11

C $\quad 1-12$

C $1-12$

VC $1-12$

C $1-12$

C $1-12$

VC $\quad 1-12$

NC 7-11

NC 7-11

NC 7-11

VC 1-12

NC $1-12$

NC $\quad 1-12$

R $1-6,12$

Ambient Science (2014)

http://www.caves.res.in/ 